\title{
A Referendum on the Carbon Tax? The 2013 Australian election, the Greens and the environment
}

Christopher Rootes,

Centre for the Study of Social \& Political Movements,

School of Social Policy, Sociology \& Social Research,

University of Kent, Canterbury, UK

Email: c.a.rootes@kent.ac.uk

[pre-publication version of article published in Environmental Politics, 23 (1): 166-

173. (2014). DOI:10.1080/09644016.2014.878088. ISSN 0964-4016

print/ISSN 1743-8934 online.]

The 7 September 2013 election brought to an end the most extraordinary parliament in Australia's recent political history. A minority Labor government, sustained in office by pacts with the Greens and three independent MPs, not only completed a full three-year term but secured the passage of more legislation than any of its predecessors, introduced a plethora of substantive reforms, including a carbon pricing regime, and presided over an unprecedented rise in the living standards of working Australians. Yet it was persistently denounced by the Liberal opposition as 'the worst Australian government ever' and suffered a shattering defeat at the polls.

\section{The campaign}

From the moment that Prime Minister Julia Gillard agreed in 2010 to Greens and independent MPs' demands that carbon pricing should be introduced, opposition leader Tony Abbott ran a relentlessly negative campaign against her government. Appearing never to accept its legitimacy, Abbott incessantly attacked its climate change measures, for which he claimed the government had no mandate.

Labelling the government's carbon pricing scheme 'a great big tax on everything', Abbott asserted that its introduction broke Gillard's pre-election promise not to introduce a carbon tax, omitting to acknowledge that throughout the 2010 campaign Gillard had made it clear that she was determined to introduce a carbon pricing scheme, albeit after further public consultation. However, tiring of Abbott's persistent hectoring and in the hope of moving on to discussion of substantive issues, Gillard ceased contesting Abbott's labelling carbon pricing a tax. This, she later admitted, was an error. Thereafter Abbott never stopped branding her a liar.

This was, in effect, the longest election campaign in Australian history. Gillard had agreed in 2010 that parliament should run for a full three years and, in June 2013, she ended speculation by announcing that the election would be on 14 September. The polls suggested that Labor would suffer massive losses under Gillard, but might do considerably better with former leader, Kevin Rudd, and so Rudd, who had never concealed his conviction that he was illegitimately ousted 
from the Prime Ministership in 2010, again challenged Gillard for the Labor leadership. Rudd's return as Prime Minister was followed by a blitz of policy revisions, but, concerned that the associated bounce in the polls would fade, Rudd brought the election forward to 7 September, leaving five weeks for formal campaigning.

To defuse Abbott's attacks on the 'carbon tax', Rudd announced the acceleration to mid-2014 of its replacement by an emissions trading scheme (ETS), previously scheduled for 2015 , which polls showed to be more popular than the maligned 'tax'. If this presented Abbott with a problem, he ignored it. All Rudd was proposing, Abbott claimed, was to replace a fixed-rate tax with a floatingrate one.

Abbott, in election campaign mode throughout the parliament, switched from opposition attack dog to potential Prime Minister in the final throes. Yet he did not stop denouncing an allegedly looming economic crisis and an 'out of control budget deficit' that the IMF observed was much smaller than those of other developed countries. Predictions of crisis evaporated in the last week of the campaign, and the Liberal-National coalition's eve of poll costings revealed it would only lightly prune spending, cutting Labor programmes only to reallocate funds to coalition schemes.

Seasoned observers judged the campaign to have been the most dispiriting they had witnessed. Serious discussion of issues was notably absent as Rudd focused on his rather than Abbott's suitability to be Prime Minister, while Abbott asserted Labor's economic incompetence and unfitness to govern.

\section{The results}

The election gave Abbott's coalition a 30-seat majority in the 150 member House of Representatives (see Table 1). Yet the coalition achieved a swing towards it of only $1.8 \%$. Labor, however, suffered a swing against it of $4.5 \%$; the swing against the Greens (3.1\%) was, as a proportion of its vote, even greater. The result was thus more a vote against the Greens-supported Labor government than an enthusiastic embrace of Abbott's alternative; the chief beneficiaries were independents and micro-parties.

Table 1 about here

Table 1. House of Representatives election 2013 - aggregated national vote

\begin{tabular}{|c|c|c|c|c|}
\hline & $\begin{array}{l}\% \text { share } \\
\text { of vote }\end{array}$ & $\begin{array}{l}\% \text { Change } \\
\text { from } 2010\end{array}$ & $\begin{array}{l}\text { Seats } \\
\text { won }\end{array}$ & $\begin{array}{l}\text { Change } \\
\text { in seats }\end{array}$ \\
\hline Liberal/National & 45.5 & +1.8 & 90 & +17 \\
\hline Labor Party & 33.4 & -4.5 & 55 & -17 \\
\hline The Greens & 8.6 & -3.1 & 1 & +0 \\
\hline Others & 12.4 & +5.8 & 4 & +0 \\
\hline
\end{tabular}


The concurrent Senate election produced a swing to the coalition of less than $1 \%$, the balance of power shifting to a gaggle of micro-parties (see Table 2). These, mostly representing narrow special interests, included the Australian Motoring Enthusiasts Party and the Palmer United Party, which won two seats despite being established only months before the election by coal-mining magnate Clive Palmer, who himself won a House seat.

Table 2 about here

Table 2. Senate election 2013 - aggregated national vote

$\begin{array}{llllll} & \begin{array}{l}\text { \% share } \\ \text { of vote }\end{array} & \begin{array}{l}\text { \% Change } \\ \text { from 2010 }\end{array} & \begin{array}{l}\text { Seats } \\ \text { won }\end{array} & \begin{array}{l}\text { Net Change } \\ \text { in seats }\end{array} & \begin{array}{l}\text { New Senate } \\ \text { (from July 2014) }\end{array} \\ \text { Liberal/National } & 37.7 & -0.8 & 17 & -1 & 33 \\ \text { Labor Party } & 30.2 & -5.0 & 12 & -6 & 25 \\ \text { The Greens } & 8.6 & -4.5 & 4 & +1 & 10 \\ \text { Others } & 23.6 & +10.5 & 7 & +6 & 8\end{array}$

\section{The Greens}

Measured by seats, if not votes, the Greens held their ground. Deputy Leader Adam Bandt retained the seat of Melbourne, increasing his vote. The Greens gained a Senate seat in Victoria, to give them an unprecedented 11 members of the federal parliament.

Nevertheless, this election marked the first serious check in the Greens' rising share of the national vote. However, the gap between the party's performance in the Senate and the House, which widened markedly in 2010, disappeared in 2013. This suggests that the Greens' 8.6\% may represent the party's new core level of support. Indeed, it is possible that the number of Greens 'identifiers' in 2013 was actually greater than the $5.9 \%$ who identified with the party in 2010 (Miragliotta 2013: 712). Certainly, the demographics of the Greens vote are encouraging: pre-election opinion polls showed a linear decline in the Greens share of vote with age, the youngest voters being more than twice as likely as those over 65 to prefer the Greens. All else being equal, generational turnover promises a steady increase in the Greens vote.

So, if the core of Greens identifiers remained solid or perhaps increased, why did the Greens lose so many votes? Some blamed the change of leadership from the 'avuncular' Bob Brown to the sometimes 'shrill' Christine Milne. Some blamed the Greens for the Gillard government's introduction of the 'carbon tax'. ${ }^{1}$ In fact, in a highly polarised election in which the personalities of Abbott and Rudd loomed larger than any discussion of policies, the Greens were largely ignored.

${ }^{1}$ As Crowley (2013, p. 379) put it, 'minority government politics created the window of opportunity' to introduce carbon pricing'. 
Early in the campaign, when Rudd and Abbott seemed determined to prove that each could be tougher than the other in dealing with the boatloads of refugees arriving in Australia's territorial waters, it appeared that the Greens might benefit from the disgust of voters who saw the major parties' policies as inhumane. But the Greens did not have a monopoly of humanity toward refugees; it was also an issue for Palmer. More importantly, with both Rudd and Abbott promising to stop the boats, the issue slipped from the headlines. Some former Greens voters deserted the party because they believed it was prioritising asylum-seekers over environmental concerns, especially by agreeing to exchange preferences with Palmer's party.

In previous elections many voters chose between major party candidates for the House but voted Greens in the Senate. Faced with fading poll figures, Milne made a last minute appeal to voters to vote Greens to deny an Abbott government unfettered scope to pass radical legislation. But in 2013 the abundance of alternatives meant that the Greens faced much stiffer competition for the protest vote. Nor was a party that for most of the parliament had been formally committed to sustaining an unpopular government a plausible destination for a protest vote. With the two issues on which the Greens had the strongest profile asylum seekers and climate change - ranking low among voters' concerns ${ }^{2}$, the Greens were marginalised, especially when the Liberals, who in 2010 preferenced the Greens ahead of Labor, in 2013 deliberately put the Greens last in the hope of eliminating them from the electoral landscape.

Where do the Greens go from here? Although their Senate vote was down by a third compared with 2010, it was only marginally below the party's 2007 result. Remarkably, both nationally and in the five most populous states, the Greens' share of the House vote in 2013 was actually greater than in 2007; only in Tasmania was it lower. An exit poll suggested that a third of those who voted Green in 2010 would have voted Labor but for Labor's abandonment of emissions trading (Rootes 2011, p. 413); in 2013, with Labor committed to an ETS, those voters might simply have returned to Labor in its hour of need. Thus the 2010 result may be an anomaly in the longer-term trend of steadily rising Greens support.

The Greens remain the third party both in seats won and share of the vote, but will have to operate with greatly reduced resources. Because public funding of political parties is proportionate to the votes they secure at elections, the Greens' funding falls from $\$ 7.1$ million in 2010 to $\$ 5.4$ million. This will make it more difficult for the Greens to defend the six Senate seats - one in every original state - won in 2010.

\footnotetext{
${ }^{2}$ Asked which of eleven issues would be important to the way they voted, respondents ranked health, the economy and education well ahead of asylum seekers $\left(7^{\text {th }}\right)$; climate change ranked $11^{\text {th }}$. (Newspoll for The Australian, http://polling.newspoll.com.au.tmp.anchor.net.au/image_uploads/130803\%20I ssues.pdf [accessed 31.10.2013]).
} 
Greens gained votes in only 11 House seats, with best results in Melbourne and two neighbouring seats. They lost ground in inner city target seats outside Melbourne, Little suggests that the party will soon gain further House seats

One of several senior staff who resigned after the election cited differences with Milne over strategy. Her attempt to reach beyond the Greens' urban bases spread resources thinly with negligible results. The Greens' direction of preferences to parties opposed to any carbon pricing contributed to the election of at least one Senator radically opposed to Greens' environmental policies over a rival, more sympathetic candidate. Nevertheless, in the mandatory post-election leadership ballot, Milne was re-elected unopposed.

\section{The environment}

Commentators remarked the absence of the environment as an issue during the campaign but, in the final week, Abbott declared the election 'a referendum on the carbon tax', which he claimed would rise from $\$ 24.15$ per tonne in $2013-14$ to $\$ 350$ a tonne by 2050 and devastate the economy without reducing Australia's greenhouse gas (GHG) emissions. An $80 \%$ cut in emissions could only be achieved by purchasing over $\$ 3$ billion of carbon credits from abroad, which, Abbott declared, would be "by far the biggest wealth transfer from Australians to foreigners that's ever been contemplated', ignoring the fact that international carbon trading is designed to allow nations with different competitive advantages to collectively reduce carbon emissions at least cost.

Abbott reiterated the misleading claim that the carbon price is simply a tax. Yet the carbon pricing scheme appears to have been effective in reducing emissions without incurring the heavy economic burdens the coalition alleged. A transitional scheme that involves purchase and surrender of emission permits as a step toward an ETS, its burden on households is essentially nil because they were compensated for the increased costs of energy even as polluters were given clear price signals to reduce their emissions. The politically expedient ETS would have started with a much lower carbon price but, linked to the variable pricing of the EU ETS scheme, would have entailed less certainty about both the carbon price and its effects.

The details of the coalition's alternative 'Direct Action' plan remain obscure, but its basic thrust is that, rather than depending on a market mechanism to discourage GHG emissions, government will pay industry and farmers to reduce emissions and will incentivise installation of renewable energy infrastructure and activities such as tree planting designed to absorb carbon.

Aside from the irony that a Liberal government should prefer empowering bureaucrats to allocate permits and incentives to relying upon a more efficient market mechanism, the problem for the coalition is that few informed observers are confident that Direct Action will effectively reduce emissions at acceptable cost. A post-election survey of 35 prominent economists found that while 30 favoured the existing carbon price scheme, only two believed Direct Action was 
the better way to reduce Australia's GHG emissions. Pre-election reports for the Treasury, the Climate Institute and WWF all concluded that, in order to meet the $5 \%$ emissions reduction target by 2020, Direct Action would cost far more than the $\$ 3.2$ billion estimated by the coalition, and possibly as much as $\$ 35$ billion (Edis 2013).

Abbott also promised that his government would spend only as much as it had budgeted: 'We will get as much environmental improvement, as much emissions reduction as we can for the spending that we've budgeted.' The implication was clear: if critics' predictions that it will cost far more to achieve the 5\% GHG reduction than the coalition has budgeted, then it is the carbon reduction target that will be sacrificed, not the budget. Yet even before the election, the coalition pruned its budget for Direct Action from $\$ 3.2$ billion to $\$ 2.88$ billion, chiefly by reducing funding for renewable energy.

\section{Prospects}

A former colleague suggested that Abbott will be a traditional, socially and economically conservative Prime Minister, rather than a neo-liberal radical (The Age 9.9.13), but nothing in Abbott's declarations before, during and since the election suggests that he will be conservative with regard to environmental protection.

On its first day in office, the Abbott government ordered the Clean Energy Finance Corporation (CEFC) to cease making investments, and abolished the Department of Climate Change and the independent Climate Commission, shifting its responsibilities to the Department of Environment. It also moved to abolish the independent Climate Change Authority (CCA). This was justified on grounds of cost, but since the sums so saved are very modest, the suspicion is that the real reasons are ideological. Nevertheless, the significance of these changes may be chiefly symbolic. The bonfire of climate institutions may not presage the abandonment of action on climate change.

Australia remains committed to its obligations under the Kyoto Protocol, and to the reduction of GHG emissions by $5 \%$ by 2020 . Because abolishing the CEFC and the CCA requires legislation that the government cannot hope to pass through the Senate before July 2014, both will continue to operate in the interim. The new Environment Minister, Greg Hunt, despite his credibility-straining defence of Direct Action during the election campaign, has since declared his confidence that there will be effective global action on climate change, especially because of China's growing commitment. Moreover, Hunt, a longstanding advocate of abating pollution by taxation, appears content to let the CCA complete its review of emissions caps and targets, which is expected to recommend raising Australia's emissions reduction target well above 5\%.

Perhaps, in opposing Labor's carbon pricing scheme so vehemently, Abbott simply opportunistically wielded the stick gifted him by Labor's prevarication over the issue. In 2009, Abbott described himself as 'a bit of a weather vane' on 
climate change, and his more extravagant utterances during the campaign may have been more a rhetorical gesture to the right than an intimation of personal skepticism. Certainly, Abbott asserted both during and after the election that climate change is real and that strong action should be taken against it.

There are signs that the public response to the Abbott government's manoeuvres may not be passive: in less than a week, a Facebook campaign raised more than $\$ 900,000$ from over 20,000 private donors to fund a Climate Council to replace the now abolished Climate Commission and to fulfill its remit of providing the public with apolitical information on the science of global warming. It would be a nice irony if the government's attempt to bury climate change in the depths of the bureaucracy should stimulate the public mobilization around climate change that Australia has so far lacked.

The relationship between the government and the Climate Council looks set to be conflictual. When Abbott declared that claims of a link between climate change and the unprecedentedly early October 2013 bushfires around Sydney were 'complete hogwash', and Hunt supported him by citing Wikipedia as authority for Abbott's proposition that bushfires had always been a feature of Australian life, the Climate Council's Professor Will Steffen expressed frustration that Abbott and Hunt refused to accept scientific evidence that climate change increases the probability of more intense fires and longer fire seasons.

Even if the changes in Australian climate policy amount to less than the headlines suggest, in other respects the environment remains very much in question. Even as Abbott's climate policy envisages sequestering carbon by afforestation, his government proposes to relax constraints upon land-clearing, tear up the Tasmanian forests agreement, remove World Heritage status from significant areas of Tasmanian old-growth forests in order to facilitate the resumption of logging, fast-track approvals of new infrastructure and resource extraction developments, and switch investment from public transport to new, preferably toll-free, roads.

Abbott may draw back from some of these controversial measures. He may, for example, be persuaded by warnings from the Tasmanian forestry industry that to scrap the forests agreement could actually set the industry back, because it would threaten FSC (Forest Stewardship Council) certification and make Australian forest products unexportable to the most profitable markets.

Abbott has declared that he has a mandate to repeal the carbon tax and will brook no opposition, but any attempt to bully a Senate he does not control may backfire. Until the new Senators take their seats in July 2014, Abbott will face in the Senate a Labor - Greens majority committed to an ETS. Abbott will also lack a majority in the new Senate, and his ability to repeal carbon pricing will depend on negotiations with Senators representing micro-parties. However, since all but one of them oppose carbon pricing, it is unlikely to survive. The focus will then be on Direct Action. 


\section{Acknowledgements}

The information on which this Profile is based was sourced principally from the Australian Broadcasting Corporation (abc.net.au), The Age, Sydney Morning Herald, Canberra Times, Climate Spectator

(http://www.businessspectator.com.au/climate) and the Australian Electoral Commission (aec.gov.au). I thank Neil Carter, Kate Crowley, Ian McAllister, Narelle Miragliotta and Bruce Tranter for comments on earlier drafts.

\section{References}

Crowley, K. (2013). Irresistible Force? Achieving Carbon Pricing in Australia. Australian Journal of Politics and History, 59 (3): 368-381.

Edis, T. (2013). Direct Action - could it be a $\$ 35 \mathrm{~b}$ budget blowout? http://www.businessspectator.com.au/article/2013/8/30/policypolitics/direct-action-could-it-be-35b-budget-blowout (Accessed 31.8.2013).

Miragliotta, N. (2013). The Australian Greens: carving out space in a two-party system. Environmental Politics, 22 (5): 706-727.

Rootes, C. (2011). Denied, deferred, triumphant? Climate change, carbon trading and the Greens in the Australian federal election of 21 August 2010. Environmental Politics, 20 (3): 410-417. 